\title{
Perbandingan Hasil Pemeriksaan Hemoglobin Metode Azidemet Hemoglobin dan Cyanide-Free
}

\author{
Result Comparisson Hemoglobin Examination Azidemet Hemoglobin and Cyanide-Free Methods
}

\author{
Estu Sami Asih, Diah Pramudianti, dan Lucia Sincu Gunawan* \\ Fakultas Ilmu Kesehatan, Universitas Setia Budi \\ *Corresponding author : sincugunawan@gmail.com
}

\section{ABSTRAK}

Hemoglobin (Hb) adalah komponen utama sel darah merah atau eritrosit yang terdiri dari heme dan globin. Pemeriksaan Hb otomatis dapat dilakukan diantaranya dengan metode Azidemet Hb pada alat Point Of Care Testing (POCT) dan metode Cyanide-free pada alat Hematology Analyzer. Penelitian untukmengetahui perbedaan hasil pemeriksaan Hb metode Azidemet Hb dan Cyanide-free.

Penelitian bersifat observasi analitik cross sectional, dilakukan pada 78 sampel menggunakan alat Quick Chek dan Cell Dyn Ruby di Instalasi Patologi Klinik Rumah Sakit Umum Daerah (RSUD) dr. Moewardi di Surakarta pada bulan Mei - Juni 2017, digunakan uji perbedaan Independent Sample T-Test dan Paired Sample T-Test dengan signifikansi 0,05 dan interval kepercayaan (IK)

Karakteristik subjek penelitian mean \pm Standard Deviation (SD) umur 51,6 $\pm 12,89$ tahun, perempuan 50 (64,1\%), laki-laki 28 (35,9\%). Hasil mean $\pm S D$ kadar Hb metode Azidemet Hb (darah kapiler), Cyanide-free (darah vena), dan Azidemet Hb (darah vena) adalah 11,75 1, $65 \mathrm{~g} / \mathrm{dl}, 11,57 \pm 1,77 \mathrm{~g} / \mathrm{dl}$, dan $11,43 \pm 1,65 \mathrm{~g} / \mathrm{dl}$.

Tidak ada perbedaan yang signifikan ( $p=0,51$ ) hasil pemeriksaan $\mathrm{Hb}$ metode Azidemet $\mathrm{Hb}$ (darah kapiler) dan Cyanide-free (darah vena). Ada perbedaan yang signifikan $(p=0,01)$ hasil pemeriksaan $\mathrm{Hb}$ metode Azidemet $\mathrm{Hb}$ (darah vena) dan Cyanide-free (darah vena). Metode Azidemet Hb disarankan hanya digunakan untuk sampel darah kapiler, perlu penelitian lebih lanjut dengan metode dan jenis sampel yang lain.

Kata kunci : Hemoglobin, metode Azidemet Hb, metode Cyanide-free

\section{ABSTRACT}

Hemoglobin (Hb) is the main component of red blood cells or erythrocyte which comes from heme and globin. Hb examination can be automatically done using Azidemet Hb method on Point of Care Testing (POCT) device and Cyanide- free method on Hematology Analyzer. This study aims at investigating the difference of Hb examination results using Azidemet $\mathrm{Hb}$ and Cyanide-free methods.

The reseach belongs to analytical cross sectional observation carried to 78 samples using Quick Check and Cell Dyn Ruby device in Clinical Pathology Installation of Regional Public Hospital (RSUD) of dr. Moewardi in Surakarta from May to June 2017, Independent Sample T-Test and Paired Sample T-Test were carried out with significance level 0.05 dan $95 \%$ confidence interval (CI)

The characteristics of research subject indicated that the mean \pm SD age was 51,6 \pm 12.89 years, including 50 (64.1 $\%)$ female and 28 (35.9\%) male. The mean $\pm S D$ of Hb level using Azidemet Hb (capillary blood), Cyanide-free (venous blood), and Azidemet Hb (venous blood) methods are $11.75 \pm 1.65 \mathrm{~g} / \mathrm{dl}, 11.57 \pm 1.77 \mathrm{~g} / \mathrm{dl}$, and $11.43 \pm 1.65 \mathrm{~g} / \mathrm{dl}$.

There is no significant difference ( $p=51)$ of $\mathrm{Hb}$ examination result using Azidemet $\mathrm{Hb}$ (capillary blood) and Cyanide-free (venous blood) methods. There is significant difference $(p=0,01)$ of Hb examination result using Azidemet $\mathrm{Hb}$ (venous blood) and Cyanide-free (venous blood) methods. It is suggested that Azidemet Hb method is only used for capillary blood. Further research using other method and sample type is required.

Keywords : Hemoglobin, Azidemet Hb method, Cyanide-free method

\section{PENDAHULUAN}

Pemeriksaan darah rutin merupakan bagian kelompok pemeriksaan laboratorium klinik yang terdiri dari beberapa macam pemeriksaan seperti pemeriksaan kadar Hemoglobin $(\mathrm{Hb})$, hitung jenis leukosit, eritrosit, leukosit, trombosit, laju endap darah (LED) dan pemeriksaan hemostasis (Wirawan, 2011). Pemeriksaan 
kadar $\mathrm{Hb}$ merupakan pemeriksaan penunjang untuk membantu penegakan diagnosis sebagai pencerminan reaksi tubuh terhadap suatu penyakit dan sebagai petunjuk kemajuan terapi penderita anemia dan penyakit lain. Resiko yang terjadi jika penetapan kadar $\mathrm{Hb}$ tidak tepat adalah akan membuat kesalahan dalam diagnosis suatu penyakit dan pola pengobatan terhadap pasien (Gandasoebrata, 2010).

Pemeriksaan ketepatan kadar atau jumlah $\mathrm{Hb}$ yang dilakukan di laboratorium sangat dipengaruhi oleh pengalaman, kualitas reagen, cara pengambilan sampel dan cara pemeriksaan. Pemeriksaan kadar $\mathrm{Hb}$ dapat dilakukan dengan beberapa metode seperti metode Sahli, metode Cyanmet $\mathrm{Hb}$, dengan cara manual dan otomatis (Wirawan, 2011). Dari beberapa metode pemeriksaan $\mathrm{Hb}$ tersebut metode Cyanmet $\mathrm{Hb}$ yang dianjurkan Internasional Committee for Standardization in Hematology (ICSH) sebagai gold standart pemeriksaan $\mathrm{Hb}$. Kelebihan dari metode ini adalah selain mudah dilakukan juga mempunyai standar yang stabil dan hampir semua $\mathrm{Hb}$ dapat terukur kecuali sulf $\mathrm{Hb}$. Metode Cyanmet $\mathrm{Hb}$ merupakan metode pemeriksaan yang paling akurat. Metode ini dapat menghitung secara otomatis kadar $\mathrm{Hb}$ dalam eritrosit (Person \& Pincus, 2011).

Kemajuan teknologi di bidang pemeriksaan $\mathrm{Hb}$ berhasil menciptakan metode pemeriksaan $\mathrm{Hb}$ yang bebas sianida yaitu metode Cyanide-free pada alat Hematology Analyzer (flowcytometry) yang menggunakan reagen sodium lauryl sitrat (SLS) yang secara struktur kimia mirip sinanida tetapi tidak beracun dan lebih ramah lingkungan. Selain itu juga terdapat metode Azidemet $\mathrm{Hb}$ pada alat Point OfCare Testing/POCT (reflectometry) yang lebih praktis dari segi penggunaannya.

Alat POCT menggunakan metode pemeriksaan Azidemet $\mathrm{Hb}$ dapat mengukur kadar $\mathrm{Hb}$ dengan membaca warna yang terbentuk dari sebuah reaksi antara sampel yang mengandung bahan kimia tertentu dengan reagen yang terdapat pada sebuah tes strip. Reaksi yang terbentuk dari tes strip berbanding lurus dengan kadar zat yang terdapat dalam sampel yang kemudian dibaca oleh alat dari bawah strip (Mengko, 2013). Alat POCT ini mempermudah penghitungan kadar $\mathrm{Hb}$ mulai dari cara pengambilan sampel yang mudah, dapat menggunakan darah vena, arteri maupun perifer (Price dkk, 2004). Alat ini hanya membutuhkan sedikit sampel darah, mudah dibawa ke mana-mana, tidak perlu dilakukan di laboratorium dengan syarat khusus, tidak memerlukan reagen tertentu dalam pengujiannya dan hasil yang cepat (Price dkk, 2004).

Namun hasil pemeriksaan kadar $\mathrm{Hb}$ dengan menggunakan metode Azidemet $\mathrm{Hb}$ pada alat POCT ini perlu diketahui performanya. Untuk itu perlu dilakukan penelitian dengan cara membandingkannya dengan metode lain salah satunya adalah terhadap metode Cyanide-free. Berdasarkan uraian tersebut di atas penulis ingin meneliti apakah ada perbedaan hasil pemeriksaan $\mathrm{Hb}$ metode Azidemet $\mathrm{Hb}$ pada POCT dan Cyanide-free pada Hematologyanalyzer.

\section{METODE PENELITIAN}

\section{LOKASI PENELITIAN}

Penelitian dilakukan di: Instalasi Patologi Klinik (PK) Rumah Sakit Daerah (RSUD) dr. Moewardi di Surakarta.

\section{WAKTU PENELITIAN}

Waktu penelitian dilakukan pada bulan Mei 2017 sampai dengan bulan Juni 2017.

\section{RANCANGAN PENELITIAN}

Penelitian ini merupakan jenis penelitian observasi analitik cross sectional yang membandingkan hasil pemeriksaan $\mathrm{Hb}$ metode AzidemetHb dan Cyanide-free.

\section{SUBYEK PENELITIAN}

a. Populasi terjangkau dalam penelitian ini adalah seluruh pasien yang melakukan pemerik- 
saan $\mathrm{Hb}$ di Instalasi PK RSUD dr. Moewardi di Surakarta pada bulan Mei 2017 sampai dengan bulan Juni 2017.

b. Sampel adalah sebagian dari jumlah dan karakteristik yang dimiliki oleh populasi (Sugiyono, 2012). Sampel dalam penelitian ini adalah pasien rawat jalan yang melakukan pemeriksaan $\mathrm{Hb}$ di Instalasi PK RSUD dr. Moewardi di Surakarta yang menggunakan metode Azidemet $\mathrm{Hb}$ dan Cyanide-free.

Besar sampel dalam penelitian ini ditentukan dengan rumus Isaach dan Michael (Sugiyono, 2012).

$$
\mathrm{S}=\frac{\lambda^{2} \cdot N \cdot P \cdot Q}{d^{2} \cdot(\mathrm{N}-1)+\lambda^{2} \cdot P \cdot Q}
$$

Keterangan :

$\mathrm{S}=$ Ukuran sampel

$\mathrm{N}=$ Ukuran populasi

$\lambda^{2}=$ Harga tabel chi kuadrat dengan $\mathrm{dK}=1$.

Kesalahan $5 \%=3,481$

$\mathrm{P}=$ Proporsi dalam populasi

$\mathrm{Q}=0,5$

$\mathrm{d}^{2}=$ Ketelitian (error) 0,005

Berdasarkan rumus Isaach dan Michael maka jumlah minimal sampel dapat dihitung sebagai berikut:

$$
\begin{aligned}
& S=\frac{\lambda^{2} \cdot N \cdot P \cdot Q}{d^{2} \cdot(N-1)+\lambda^{2} \cdot P \cdot Q} \\
& S=\frac{3,481 \times 100 \times 0,5 \times 0,5}{0,05^{2} \cdot \times(100-1)+3,481 \times 0,5 \times 0,5} \\
& S=\frac{87,025}{1,11771} \\
& S=77,86=78 \text { sampel }
\end{aligned}
$$

\section{c. Kriteria inklusi}

Bersedia mengikuti dan menandatangani lembar persetujuan.

d. Kriteria eksklusi

1) Hemolisis yang dilihat dari warna plasma sampel yang berwarna merah.

2) Kekeruhan yang dilihat dari warna plasma sampel yang berwarna keruh (lipemik dan leukositosis)

\section{BAHAN \& ALAT}

a. BAHAN
i. Darah kapiler dan vena
ii. Bahan kontrol Abbot Lot 703
iii. Strip kontrol Quick Check
iv. Strip tes Quick Check
v. Reagen SLS

\section{b. ALAT}
i. Kit Quick Check
ii. Cell Dyn Ruby
iii. Tabung vaccutainer (EDTA)
iv. Rak tabung
v. Spuit $3 \mathrm{ml}$
vi. Kapas alcohol

\section{PROSEDUR PEMERIKSAAN \\ a. Pengambilan sampel darah}

\section{i. Darah kapiler}

Pada orang dewasa pakailah ujung jari, untuk mengambil darah kapiler pada bayi dan anak kecil boleh juga pada tumit. Tempat yang dipilih tidak boleh yang memperlihatkan gangguan peredaran darah seperti sianosis atau pucat.

a) Bersihkan tempat itu memakai kapas alkohol $70 \%$ dan biarkan sampai kering lagi.

b) Tusuk bagian yang akan ditusuk dengan menggunakan lancet yang steril kira-kira 2 $3 \mathrm{~mm}$.

c) Hapus tetesan yang pertama dengan menggunakan kapas kering,

d) Tetes darah yang berikutnya boleh dipakai untuk pemeriksaan (Dacie \& Lewis, 2011).

ii. Pengambilan darah vena

Biasanya pada orang dewasa dipakai salah satu vena dalam fossacubity; pada bayi vena jugularis superficialis atau darah dari sinus sagittalis superior.

a) Membersihkan tempat yang akan ditusuk dengan alkohol $70 \%$ dan biarkan sampai kering lagi. 
b) Memasang ikatan pembendung pada lengan atas dan meminta pasien untuk mengepal dan membuka tangannya berulang kali agar darah vena dapat terlihat jelas. Pembendungan vena tidak perlu dengan ikatan erat- erat, bahkan sebaiknya cukup erat saja, hanya untuk memperlihatkan dan menonjolkan vena yang akan ditusuk. Sebaiknya pembendungan dilakukan dalam waktu maksimal 1 menit.

c) Menegangkan kulit di atas vena dengan jari-jari tangan kiri, supaya vena tidak dapat bergerak.

d) Menusuk kulit dengan jarum dan syringe dalam tangan kanan sampai ujung masuk ke dalam lumen vena dengan kemiringan 30 derajat.

e) Melepaskan dan merenggangkan pembendungan dengan perlahan-lahan kemudian menarik penghisap syringe sampai jumlah darah yang dikehendaki didapat.

f) Melepaskan pembendung jika masih terpasang

g) Menaruh kapas di atas tempat suntikan dan mencabut syringe dan jarum tersebut.

h) Meminta kepada orang yang darahnya diambil supaya tempat tusukan itu ditekan selama beberapa menit dengan kapas tadi.

I) Jika menggunakan vacuntainer maka tabung akan dengan sendirinya terisi oleh darah, namun apabila pengambilan darah dilakukan dengan syringe tancapkan jarum pada penutup tabung vacuum dan darah akan dengan sendirinya mengalir (jangan menekan plunger pada jarum suntik, tekanan tambahan akan menyebabkan hemolisis. Apabila tabung tidak mempunyai penutup karet maka sampel dialirkan perlahan-lahan melalui dinding tabung untuk meminimalkan tekanan sehingga dapat mencegah terjadinya hemolisis (WHO, 2010).

\section{b. Metote Azidemet $\mathrm{Hb}$}

Prinsip metode pemeriksaan ini adalah eritrosit yang terhemolisa akan mengeluarkan $\mathrm{Hb}$, kemudian $\mathrm{Hb}$ ini dikonversi menjadi met $\mathrm{Hb}$ dan digabungkan dengan azide untuk membentuk azidemet $\mathrm{Hb}$. Absorban yang diukur pada panjang gelombang $570 \mathrm{~nm}$ dan $880 \mathrm{~nm}$. Absorban yang diukur berbanding lurus dengan kadar $\mathrm{Hb}$.

Carakerja:

1) Validasi alat ( otomatis)

a) Siapkan semua peralatan dan bahan yang akan digunakan.

b) Nyalakan alat QuickCheck.

c) Keluarkan strip kontrol dan tutup kembali kaleng strip dengan rapat

d) Masukkan strip kontrol setelah simbol strip berkedip, jika pada layar tampak kata "YES" maka alat siap digunakan, setelah itu cabut strip kontrol.

2) Pengerjaan sampel

a) Nyalakan alat dengan cara menekan tombol power, tunggu sampai simbol masukkan strip tampak pada layar.

b) Pastikan kode pada layar display sama dengan kode pada kaleng strip dan kode chip .

c) Ambil darah dengan menggunakan pipet yang tersedia.

d) Teteskan 10 ul darah ke dalam area strip tes.

e) Jangan meneteskan darah langsung dari jari ke atas strip.

f) Jika jumlah darah cukup maka alat akan berbunyi dan memulai pembacaan.

g) Hasil kadar $\mathrm{Hb}$ akan tampak pada layar dalam waktu 4 sampai 15 detik dengan nilai hematokrit (Hct) pada bagian bawah.

h) Layar akan otomatis mati dalam 8 menit atau jika tombol power ditekan.

3) Cara mematikan alat

a) Setelah selesai pembacaan hasil, strip tes dicabut.

b) Mematikan alat dengan cara menekan tombol power kemudian mencabut baterainya.

4) Kontrol kualitas dilakukan sesuai dengan prosedur yang berlaku di suatu tempat. 


\section{c. Metode Cyanide-free}

1). Prinsip: reagen pelisis $\mathrm{Hb}$ akan melisiskan eritrosit dan merubah $\mathrm{Hb}$ yang dibebaskan melalui proses kimia bebas sianida menjadi met $\mathrm{Hb}$, absorban kemudian diukur pada panjang gelombang $555 \mathrm{~nm}$. Absorban berbanding lurus dengan konsentrasi sampel.

2). Cara kerja Cell Dyn Ruby

a) Cara menyalakan alat.

i. Tekan agak lama power data module (sebelah kanan alat).

ii. Tekan tombol pada monitor.

iii. Tunggu sampai layar monitor muncul initialized

iv. Ganti log on menjadi admin.

v. Tekan tombol prime/F12.

vi. Tunggu sampai layar monitor ready.

vii. Alat siap digunakan.

b) Menjalankan/running background.

I. Dalam menu next open tube entry, pilih background dari menu spesimen ID atau QCID.

ii. Tekan touch plate untuk memulai run background.

iii. Pastikan background masuk dalam range (tulisan berwarna putih) run kontrol dan pasien

c) Cara menjalankan sampel pasien (open mode)

i. Pastikan alat dalam keadaan ready dan open mode.

ii. Masukkan data pasien di bagian spesimen ID QCID.

iii. Pastikan pilihan test $\mathrm{CBC}$ dari menu drop down test selection

iv. Pilihlah tombol more spec info untuk memastikan, menambah atau mengubah informasi demografi pada box dialog nextopen tube entry (detailed).

v. Buka tabung sampel dan tempatkan di bawah probe open mode.

vi. Tekan touch plate untuk aspirasi sampel.

vii. Hasil pasien akan masuk ke data log dan terpampang di layar run.

d) Cara menjalankan sampel pasien (closed mode)

i. Pastikan alat dalam keadaan ready dan closed mode.

ii. Jika masih dalam keadaan open maka tekan select closed/F11. (3) Pilih F11/star leader.

iii. Sample loader akan memproses otomatis sampelnya.

iv. Jika akan memberhentikan sample loader maka pilih F12/stop loader.

v. Rak terakhir akan bergerak ke bagian unload sample loader jika proses sudah selesai.

vi. Hasil pasien akan masuk ke date log dan terpampang di layar run.

\section{HASIL DAN PEMBAHASAN}

\section{Validasi Uji Analitik}

Uji penampilan analitik dilakukan terlebih dahulu sebelum melakukan pemeriksaan sampel penelitian. Uji analitik ini meliputi uji presisi/ketelitian dan uji akurasi/ketepatan.

\section{a. Uji Presisi/Ketelitian}

Perbedaan hasil yang diperbolehkan dalam pengukuran berulang adalah $\mathrm{CV} \pm 3 \%$ (Mengko, 2013). Untuk uji presisi kadar $\mathrm{Hb}$ metode Azidemet $\mathrm{Hb}$ menggunakan strip kontrol dan uji presisi metode Cyanide-free menggunakan darah kontrol. Hasil uji presisi dapat dilihat pada Tabel 1.

Pada Tabel 1 terlihat hasil uji presisi metode Azidemet $\mathrm{Hb} \leq 2 \%$ dan hasil presisi metode Cyanide-free didapatkan nilai $\mathrm{CV}=1,42 \%$ karena nilai $\mathrm{CV} \pm 3 \%$ maka ini berarti hasil uji presisi adalah teliti.

\section{b. Uji Akurasi}

Uji akurasi untuk metode Azidemet $\mathrm{Hb}$ menggunakan strip kontrol dan metode Cyanide-free menggunakan darah kontrol. Hasil uji akurasi dapat dilihat pada Tabel 6 . 
Tabel 1. Hasil uji presisi hari ke hari metode Azidemet $\mathrm{Hb}$ dan Cyanide-free

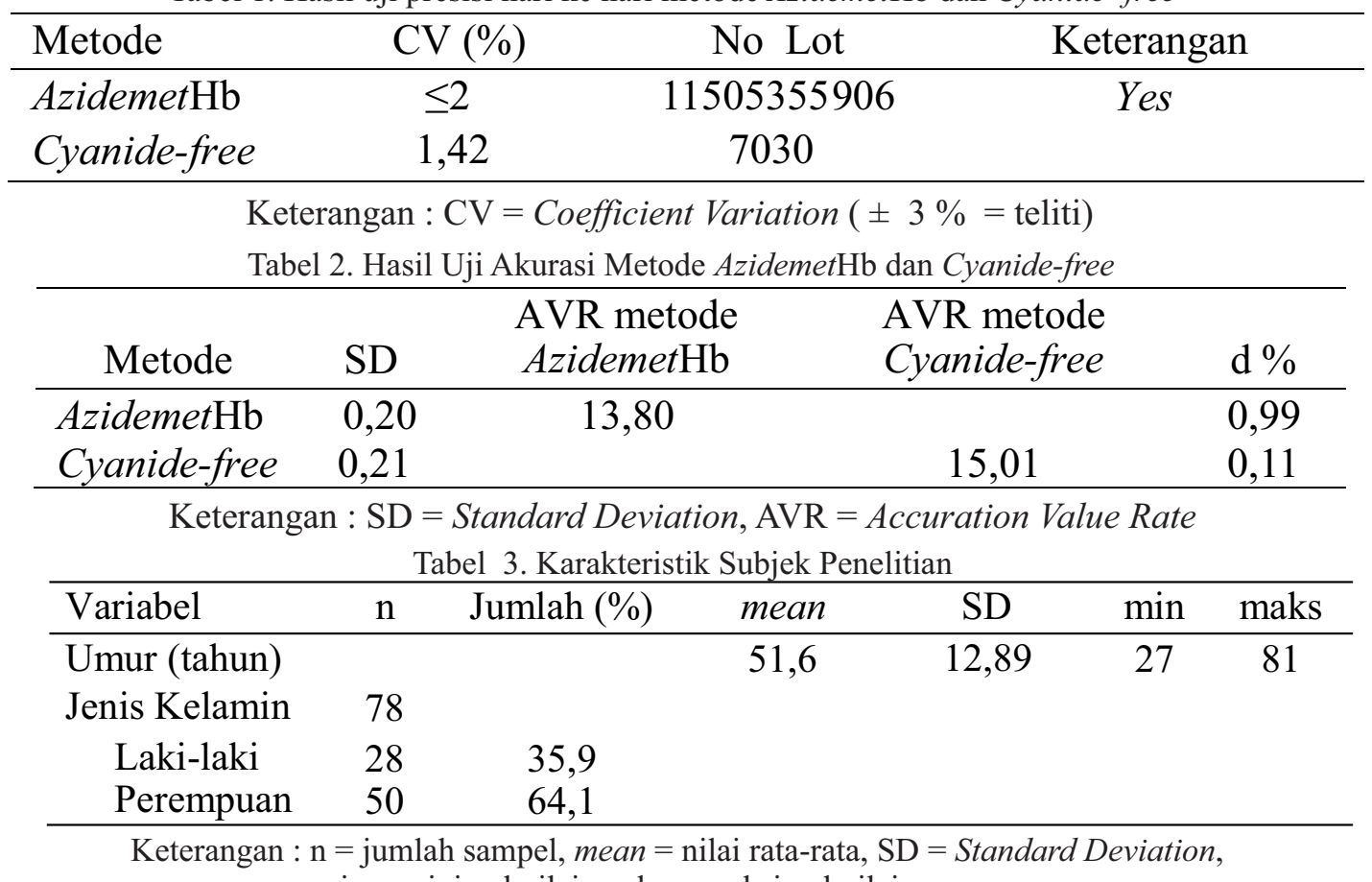
$\min =$ minimal nilai, maks $=$ maksimal nilai

Pada Table 2 terlihat hasil uji akurasi metode Azidemet $\mathrm{Hb}$ adalah AVR 13,8 g/dl ini berarti hasil uji akurasi masuk dalam rentang nilai kontrol. Untuk hasil uji akurasi kadar $\mathrm{Hb}$ Cyanidefree adalah $\mathrm{AVR}=15,01 \mathrm{~g} / \mathrm{dl}$ dan ini berarti hasil uji akurasi metode Cyanide-free masuk dalam rentang nilai kontrol, karena hasil uji akurasi kedua metode masuk rentang nilai kontrol maka hasil uji akurasi adalah tepat/akurat.

Berdasarkan hasil uji presisi dan akurasi kedua metode yang teliti dan akurat maka penelitian perbandingan hasil pemeriksaan $\mathrm{Hb}$ metode Azidemet $\mathrm{Hb}$ dan Cyanide-free dapat dilakukan.

\section{Karakteristik Subjek Penelitian}

Penelitian perbandingan hasil pemeriksaan $\mathrm{Hb}$ metode AzidemetHb dan Cyanide-free dilakukan di Instalasi PK RSUD dr. Moewardi di Surakarta. Penelitian ini dilakukan pada bulan Mei sampai dengan bulan Juni 2017 pada pasien rawat jalan yang memenuhi kriteria inklusi dan eksklusi. Karakteristik subjek penelitian dapat dilihat pada Tabel 3.

Berdasarkan Tabel 3 karakteristik subjek penelitian berjumlah 78 sampel terdiri dari 28 laki-laki (35,9\%) dan 50 perempuan (64,1\%). Mean \pm SD umur secara keseluruhan adalah $51,6 \pm 12,89$ tahun dengan umur paling muda 27 tahun dan paling tua adalah 81 tahun dan sampel terbanyak adalah perempuan.

\section{Uji Normalitas}

Data penelitian yang diperoleh kemudian dianalisis dengan uji normalitas untuk melihat apakah data hasil pengukuran kadar Hb terdistribusi normal atau tidak, sehingga dapat ditentukan uji analisis data apa yang akan digunakan. Uji Normalitas data yang digunakan adalah Kolmogorov-Smirnov Test, di mana jika nilai p $>0,05$ maka asumsi normalitas terpenuhi. Hasil uji normalitas dapat dilihat pada Tabel 4 dan 5.

Pada Tabel 4 diketahui bahwa metode Azidemet $\mathrm{Hb}$ yang menggunakan sampel darah kapiler diperoleh $\mathrm{n}$ sebanyak 78 sampel, nilai mean $\pm \mathrm{SD} 11,75 \pm 1,65 \mathrm{~g} / \mathrm{dl}$, nilai minimum $6,60 \mathrm{~g} / \mathrm{dl}$, maksimum 14,60 g/dl, nilai $\mathrm{p}=0,17$ dan metode Cyanide-free yang menggunakan sampel darah vena diperoleh $\mathrm{n}$ sebanyak 78 sampel, nilai mean \pm SD 11,57 $\pm 1,77 \mathrm{~g} / \mathrm{dl}$, nilai 
Tabel 4. Hasil Uji Normalitas Metode Azidemet $\mathrm{Hb}$ dan Cyanide-free (darah kapiler dan vena)

\begin{tabular}{ccccccc}
\hline \multicolumn{1}{c}{ Metode } & $\mathrm{n}$ & mean $(\mathrm{g} / \mathrm{dl})$ & $\mathrm{SD}(\mathrm{g} / \mathrm{dl})$ & $\min (\mathrm{g} / \mathrm{dl})$ & $\mathrm{maks}(\mathrm{g} / \mathrm{dl})$ & $\mathrm{p}$ \\
\hline Azidemet $\mathrm{Hb}$ & 78 & 11,75 & 1,65 & 6,60 & 14,60 & 0,17 \\
Cyanide-free & 78 & 11,57 & 1,77 & 6,10 & 14,70 & 0,25 \\
\hline
\end{tabular}

Keterangan $: \mathrm{n}=$ jumlah sampel, mean $=$ nilai rata-rata, $\mathrm{SD}=$ Standard Deviation, $\min =$ minimal nilai, maks $=$ maksimal nilai, $\mathrm{p}>0,05=$ normal

Tabel 5. Hasil Uji Normalitas Metode Azidemet $\mathrm{Hb}$ (darah vena) dan Cyanide-free (darah vena)

\begin{tabular}{cccccccc}
\hline Metode & $\mathrm{n}$ & mean & $\begin{array}{c}\mathrm{SD} \\
(\mathrm{g} / \mathrm{dl})\end{array}$ & $\begin{array}{c}\text { Min } \\
(\mathrm{g} / \mathrm{dl})\end{array}$ & $\begin{array}{c}\text { Maks } \\
(\mathrm{g} / \mathrm{dl})\end{array}$ & $\mathrm{P}$ \\
\hline Azidemet $\mathrm{Hb}$ (darah vena) & 78 & 11,75 & 1,65 & 6,00 & 13,90 & 0,08 \\
Cyanide-fre e (darah vena) & 78 & 11,57 & 1,77 & 6,10 & 14,70 & 0,25
\end{tabular}

Keterangan $: \mathrm{n}=$ jumlah sampel, mean $=$ nilai rata-rata, $\mathrm{SD}=$ Standard Deviation, $\min =$ minimal nilai, maks $=$ maksimal nilai $, \mathrm{p}>0,05=$ normal

minimum $6,10 \mathrm{~g} / \mathrm{dl}$, maksimum 14,70 g/dl, nilai $\mathrm{p}=0,25$. Karena nilai $\mathrm{p}>0,05$ maka data Azidemet $\mathrm{Hb}$ yang menggunakan sampel darah kapiler dan Cyanide-free yang menggunakan sampel darah vena dinyatakan terdistribusi normal sehingga dapat dilakukan uji Independent Sample T-Test.

Pada Tabel 5 untuk metode Azidemet $\mathrm{Hb}$ yang menggunakan sampel darah vena diperoleh n sebanyak 78 sampel, nilai mean \pm SD kadar $\mathrm{Hb} 11,75 \pm 1,65 \mathrm{~g} / \mathrm{dl}$ dengan nilai minimal $6,00 \mathrm{~g} / \mathrm{dl}$, maksimal 14,60 $\mathrm{g} / \mathrm{dl}$, nilai $\mathrm{p}=0,08$. Untuk metode Cyanide-free yang menggunakan sampel darah vena diperoleh n sebanyak 78 sampel, nilai mean \pm SD kadar $\mathrm{Hb} 11,57 \pm 1,77$ $\mathrm{g} / \mathrm{dl}$ dengan nilai minimal $6,10 \mathrm{~g} / \mathrm{dl}$, maksimal $14,70 \mathrm{~g} / \mathrm{dl}$, nilai $\mathrm{p}=0,25$. Karena nilai $\mathrm{p}>0,05$ maka data Azidemet $\mathrm{Hb}$ yang menggunakan sampel darah vena dan Cyanide-free yang menggunakan sampel darah vena dinyatakan terdistribusi normal, sehingga dapat dilakukan uji Paired Sample T-Test.

\section{Uji Perbedaan (Uji T)}

\section{a. Independent Sample T-Test}

Independent Sample T-Test dilakukan untuk menguji perbedaan rata-rata dari dua kelompok yang tidak berhubungan (Priyatno, 2016). Jika nilai $\mathrm{p}>0,05$ berarti tidak ada perbedaan dan jika nilai $\mathrm{p}<0,05$ berarti ada perbedaan. Hasil uji perbedaan menggunakan Independent
Sample T-Test dapat dilihat pada Tabel 10.

Pada Tabel 6 diketahui bahwa metode Azidemet $\mathrm{Hb}$ yang menggunakan sampel darah kapiler diperoleh n sebanyak 78 sampel, nilai mean $\pm \mathrm{SD}$ kadar $\mathrm{Hb} 11,75 \pm 1,65 \mathrm{~g} / \mathrm{dl}$, nilai $\mathrm{p}=$ 0,51 dan metode Cyanide-free yang menggunakan sampel darah vena diperoleh nilai $\mathrm{n}$ sebanyak 78 sampel, nilai mean $\pm \mathrm{SD}$ kadar $\mathrm{Hb} 11,57$ $\pm 1,77 \mathrm{~g} / \mathrm{dl}$, nilai $\mathrm{p}=0,51$. Karena nilai $\mathrm{p}>0,05$ maka ini berarti tidak ada perbedaan yang signifikan hasil pemeriksaan $\mathrm{Hb}$ metode Azidemet $\mathrm{Hb}$ yang menggunakan sampel darah kapiler dan Cyanide-free yang menggunakan sampel darah vena.

\section{b. Paired Sample T-Test}

Paired Sample T-Test dilakukan untuk mengetahui perbedaan rata-rata dari dua kelompok sampel yang berpasangan (Priyatno, 2016). Kriterianya adalah jika $\mathrm{p}>0,05$ berarti tidak ada perbedaan dan jika $\mathrm{p}<0,05$ berarti ada perbedaan.

Pada Tabel 7 diketahui bahwa untuk metode Azidemet $\mathrm{Hb}$ yang menggunakan sampel darah vena diperoleh $\mathrm{n}$ sebanyak 78 sampel, mean \pm SD kadar Hb 11,43 g/dl \pm 1,65 g/dl, dan p=0,01. Untuk metode Cyanide-free yang menggunakan darah vena mean $\pm \mathrm{SD}$ kadar $\mathrm{Hb} 11,57 \pm 1,77$ $\mathrm{g} / \mathrm{dl}$, dan $\mathrm{p}=0,01$ karena $\mathrm{p}<0,05$ ini berarti ada perbedaan yang signifikan hasil pemeriksaan $\mathrm{Hb}$ metode Azidemet $\mathrm{Hb}$ yang menggunakan 
Tabel 6.Hasil Uji Perbedaan Metode Azidemet $\mathrm{Hb}$ (darah kapiler) dan Cyanide-free (darah vena)

\begin{tabular}{lcccc}
\hline Metode & $\mathrm{n}$ & mean $(\mathrm{g} / \mathrm{dl})$ & $\mathrm{SD}(\mathrm{g} / \mathrm{dl})$ & $\mathrm{p}$ \\
\hline Azidemet $\mathrm{Hb}$ (darah kapiler) & 78 & 11,75 & 1,65 & 0,51 \\
Cyanide-free (darah vena) & 78 & 11,57 & 1,77 & 0,51 \\
\hline
\end{tabular}

Keterangan $: \mathrm{n}=$ jumlah sampel, mean = nilai rata-rata, $\mathrm{SD}=$ Standard Deviation, $\min =$ ninimal nilai, maks $=$ maksimal nilai, $\mathrm{p}>0,05$ tidak ada perbedaan

Tabel 7. Hasil Uji Perbedaan Metode Azidemet $\mathrm{Hb}$ (darah vena) dan Cyanide-free (darah vena)

\begin{tabular}{lcccc}
\hline Metode & $\mathrm{n}$ & mean $(\mathrm{g} / \mathrm{dl})$ & $\mathrm{SD}(\mathrm{g} / \mathrm{dl})$ & $\mathrm{p}$ \\
\hline Azidemet $\mathrm{Hb}(\mathrm{vena})$ & 78 & 11,43 & 1,65 & 0,01 \\
Cyanide-free (vena) & 78 & 11,57 & 1,77 & 0,01 \\
\hline
\end{tabular}

Keterangan $: \mathrm{n}=$ jumlah data, mean $=$ nilai rata-rata, $\mathrm{SD}=$ Standard Deviation, $\mathrm{p}<0,05$ ada perbedaan

sampel darah vena dan Cyanide-free yang menggunakan sampel darah vena.

\section{PEMBAHASAN}

Uji presisi dan akurasi sangat penting dilakukan untuk memastikan suatu alat layak digunakan dan juga untuk memastikan bahwa hasil yang didapat dari pengukuran alat tersebut adalah valid. Uji presisi yang dilakukan pada penelitian ini adalah uji presisi hari ke hari (day to day) yaitu dengan melakukan pemeriksaan kontrol rutin setiap hari sebelum melakukan pemeriksaan (Sukorini dkk, 2010).

Hasil uji presisi dikatakan baik jika $\mathrm{CV} \pm$ 3\% (Mengko, 2013). Hasil uji akurasi metode Azidemet $\mathrm{Hb} \mathrm{CV} \leq 2 \%$ dan untuk metode Cyanide-free $\mathrm{CV}=1,42 \%$. Karena kedua metode memiliki nilai $\mathrm{CV} \pm 3 \%$ maka ini berarti hasil presisi kedua metode adalah teliti.

Untuk hasil akurasi dilihat apakah hasil terletak di dalam atau di luar rentang nilai kontrol, bila hasil terletak di dalam rentang nilai kontrol maka dapat dinyatakan hasil adalah tepat/akurat (Riyanto, 2014). Hasil uji akurasi metode Azidemet $\mathrm{Hb}$ adalah $\mathrm{AVR}=13,8 \mathrm{~g} / \mathrm{dl}$. Sedangkan untuk metode Cyanide-free diperoleh $\mathrm{AVR}=15,01 \mathrm{~g} / \mathrm{dl}$. Karena nilai akurasi kedua metode masuk dalam rentang nilai kontrol, maka ini berarti akurasi kedua metode adalah tepat/akurat.

Karakteristik subjek penelitian ini diperoleh jumlah sampel sebanyak 78 sampel yang terdiri atas laki-laki 28 orang $(35,5 \%)$ dan perempuan
50 orang $(64,1 \%)$ dengan sampel terbanyak adalah perempuan, mean $\pm \mathrm{SD}$ umur secara keseluruhan 51,60 $\pm 12,89$ tahun dengan minimal umur 27 tahun dan maksimal 81 tahun. Pada uji normalitas metode pengambilan keputusan adalah jika $\mathrm{p}>0,05$ maka data dinyatakan terdistribusi normal (Priyatno, 2016). Untuk metode Azidemet $\mathrm{Hb}$ yang menggunakan sampel darah kapiler memiliki $\mathrm{p}=0,17$ dan Cyanide-free yang menggunakan sampel darah vena memiliki $\mathrm{p}=0,25$ sedangkan untuk metode Azidemet $\mathrm{Hb}$ yang menggunakan sampel darah vena memiliki $\mathrm{p}=0,08$ karena $\mathrm{p}>0,05$ maka data dinyatakan terdistribusi normal.

Untuk analisis data digunakan uji perbedaan (uji T) yang bertujuan untuk mengetahui adanya perbedaan rata-rata dari sampel yang diambil (Priyatno, 2016). Uji perbedaan yang dilakukan untuk metode Azidemet $\mathrm{Hb}$ yang menggunakan sampel darah kapiler dan Cyanide-free yang menggunakan sampel darah vena adalah uji Independent Sample T-Test dimana diperoleh $\mathrm{p}$ $=0,51$ karena $\mathrm{p}>0,05$ maka ini berarti tidak ada perbedaan yang signifikan hasil pemeriksaan $\mathrm{Hb}$ metode Azidemet $\mathrm{Hb}$ yang menggunakan sampel darah kapiler dan Cyanide-free yang menggunakan sampel darah vena. Sedangkan untuk metode Azidemet $\mathrm{Hb}$ yang menggunakan sampel darah vena dan Cyanide-free yang menggunakan sampel darah vena dilakukan uji Paired Sample T-Test diperoleh $\mathrm{p}=0,01$ karena $\mathrm{p}<0,05$ maka ini berarti ada perbedaan yang signifikan hasil pemeriksaan $\mathrm{Hb}$ metode 
Azidemet $\mathrm{Hb}$ yang menggunakan sampel darah vena dan Cyanide-free yang menggunakan sampel darah vena.

Pada pengukuran kadar $\mathrm{Hb}$ metode Azidemet $\mathrm{Hb}$ dan Cyanide-free yang menggunakan jenis sampel berbeda (kapiler dan vena) didapatkan hasilnya adalah tidak ada perbedaan tetapi ketika digunakan jenis sampel yang sama (vena dan vena) hasilnya adalah ada perbedaan meskipun nilai mean \pm SD tidak jauh berbeda. Hal ini disebabkan karena uji analisis data yang digunakan berbeda. Keterbatasan dalam penelitian ini adalah:

1. Metode cross sectional hanya membandingkan hasil pemeriksaan pada saat penelitian dilakukan sehingga perlu dilakukan dengan metode cohort/ jangka panjang untuk metode Azidemet $\mathrm{Hb}$ dan Cyanide-free.

2. Penelitian ini hanya membandingkan metode Azidemet $\mathrm{Hb}$ dan Cyanide-free sedangkan masih banyak metode pemeriksaan $\mathrm{Hb}$ yang lainnya sehingga perlu dilakukan penelitian dengan metode yang lain.

3. Penelitian ini hanya membandingkan sampel darah kapiler dan vena sedangkan pada beberapa kasus penyakit atau karena kondisi pasien diperlukan pemeriksaan $\mathrm{Hb}$ dengan sampel darah arteri, cairan pleura ataupun cairan sendi.

\section{KESIMPULAN DAN SARAN KESIMPULAN}

1. Tidak ada perbedaan yang signifikan hasil pemeriksaan $\mathrm{Hb}$ metode Azidemet $\mathrm{Hb}$ yang menggunakan sampel darah kapiler dan Cyanide-free yang menggunakan sampel darah vena,
2. Ada perbedaan hasil yang signifikan pemeriksaan $\mathrm{Hb}$ metode Azidemet $\mathrm{Hb}$ yang menggunakan sampel darah vena dan Cyanide-free yang mengguna kan sampel darah vena.

\section{SARAN}

1. Perlu dilakukan uji validasi sebelum memulai pemeriksaan sampel untuk mengetahui performa dari alat atau metode yang digunakan agar hasil pengukuran dapat dipertanggungjawabkan.

2. Perlu dilakukan penelitian lebih lanjut untuk metode dan jenis sampel yang berbeda.

\section{DAFTAR PUSTAKA}

Arisman. 2007. Gizi Dalam Daur Kehidupan. Jakarta : EGC. Abbott, 2006. Cell Dyn Ruby System. Illinois. USA

Acon Biotech. 2012. Quick Chek Hb Testing User's Manual. Hangzhou.

Bain, B.J.. 2004. A Beginner's to Blood Cells. British : Blackwell Publishing Ltd. Bakta, I.M. 2007. Hematologi Klinis Ringkasan. Jakarta: EGC.

Departemen Kesehatan RI. 1989. Materia Medika Indonesia. Jilid V. Jakarta: Direktorat Jenderal Pengawasan Obat dan Makanan.

Danis, D. 2010. Kamus Istilah Kedokteran. Jakarta: Gita Media

Dacie \& Lewis, 2011. Practical Hematology. Livingstone: Elsevier Churchill.

D'Hiru. 2013. Live Blood Analysis. Jakarta: PT. Gramedia Pustaka Utama. Gandasoebrata, R. 2010. Penuntun Laboratorium Klinik. Jakarta: Dian Rakyat Guyton, A.C \& Hall. 2008. Buku Ajar Fisiologi Kedokteran. Edisi 11. Jakarta: EGC

Harjoeno, H. 2003. Interprestasi Hasil Tes Laboratorium Diagnostik. Jakarta: EGC.

Hoffbrand, V. 2005. Haematology at a Glance. Edisi 25. London: Blackwell Publishing Ltd.

Kee, J.L. 2007. Pedoman Pemeriksaan Laboratorium dan Diagnostik. Edisi 6. Jakarta: EGC.

Kosasih, E.N, \& Kosasih, A.S. 2008. Tafsiran Hasil Pemeriksaan Laboratorium Klinik. Jakarta: Karisma Publising Group.

Komandoko, G. 2013. Donor Darah Terbukti Turunkan Risiko Penyakit Jantung dan Stroke. Yogyakarta: Media Presindo. 